\title{
Environmental conditions of alpine springs of the upper Po River (NW Italy) on the basis of their epilithic diatom communities
}

\begin{abstract}
Diatom (Bacillariophyceae) assemblages were sampled in 7 springs in the upper part of the River Po basin in the summer of 2010. Four springs are situated in the mountainous part of the study area while three are in the lowland plain. Chemical-physical variables were measured and analyzed in water samples of 6 springs. 101 diatom species were identified in the surveyed springs, with species richness ranging from 12 to 52. Gomphonema nathorstii, described for arctic regions, was found in Italy for the first time. Multivariate statistical analysis was undertaken to link taxonomical and environmental data, and indicated the existence of three distinct environmental features, each one characterized by prevalent diatom species: 1) low $\mathrm{pH}$ and high dissolved oxygen, 2) both high $\mathrm{pH}$ and dissolved oxygen and 3) high levels of silica and conductivity.
\end{abstract}

Key words: Diatoms, alpine springs, ecological indicators, aquatic habitats.

Riassunto - Condizioni ambientali delle sorgenti alpine dell'Alta Valle del Fiume Po (Italia NW) sulla base delle comunità di diatomee epilitiche.

Nell'estate 2010 sono state campionate le comunità di diatomee (Bacillariophyceae) di 7 sorgenti nella parte superiore del bacino del Fiume Po. Quattro sorgenti sono situate nella parte montuosa dell'area di studio mentre tre sono collocate nella parte planiziale. Sono stati rilevati alcuni parametri chimico-fisici in campioni idrici di 6 sorgenti. Sono state identificate complessivamente 101 specie, con un minimo di 12 ed un massimo di 52 specie nelle singole sorgenti. Tra queste si segnala la presenza di Gomphonema nathorstii, primo ritrovamento in Italia, descritta per le zone artiche. L'analisi statistica multivariata ha permesso di individuare tre situazioni distinte, ognuna contraddistinta da specie prevalenti caratteristiche: una caratterizzata da bassi valori di $\mathrm{pH}$ e elevati valori di ossigeno disciolto, una da valori elevati sia di $\mathrm{pH}$ che di ossigeno disciolto ed una da valori relativamente elevati di silice e di conducibilità.

Parole chiave: Diatomee, sorgenti alpine, indicatori ecologici, habitat acquatici.

\section{Introduction}

Bacillariophyceae, commonly named Diatoms, represent an important taxonomical group of microscopical freshwater and marine algae characterized by a silica frustule. Diatoms are the object of an increasing number of studies, mainly in

ARPA Piemonte Dipartimanto di Cuneo, via Vecchia di Borgo San Dalmazzo 11, 12100 Cuneo, Italia; e-mail: m.battegazzore@arpa.piemonte.it 
relation with the known value of many of the most common species as biological indicators of ecological conditions (Van Dam et al., 1994). Over 24,000 species have been identified and about 200,000 exist (Mann \& Droop 1996). However, diatoms still remain under-represented in ecological studies of aquatic environments, despite their importance in terms of photosynthetic and trophic role at a planetary scale (Longhurst et al., 1995). In fact, diatoms, besides playing a fundamental role in the silica biogeochemical cycle, constitute significant part of the planetary biomass, thanks to a primary production rate of the order of $10^{13} \mathrm{kgC}^{-1}$, estimated to amount up to about $20-25 \%$ of the total primary production of the planet Earth (Werner, 1977). Most of the primary production occurs in the oceans, where diatoms are responsible for up to $35 \%$ of the primary producion in oligotrophic waters and up to $75 \%$ in nutrient rich areas (Tréguer et al., 1995). Nevertheless, diatoms are also important in freshwater and even terrestrial ecosystems, wherever some humidity is present (Ettl \& Gärtner, 1995).

Springs and mountain headwaters are important freshwater environments. Some studies of alpine springs have been undertaken and appear to be increasing in recent years including both diatoms (Battegazzore et al., 2004; Cantonati et al., Eds., 2007) and other biota (Orendt, 2000; Hàjkovà et al., 2007). These "marginal" but strategic environments are still scarcely considered in routine monitoring (except for those used for drinking purposes). The importance of these habitats as sources of both water and biodiversity for the surrounding territories often seems to be underestimated, even in protected areas. From an administrative and legislative point of view, attention to the importance of the environmental protection of springs still appears to be inadequate.

A survey was undertaken on a number of springs of the upper valley of the River Po (Italy's main river) and their headwaters, with the aim of building the basis for future developments of the environmental protection of these habitats. In particular, the prosecution of the survey by means of a monitoring program and its connection with similar existing projects in other areas, would be useful for the future expansion of knowledge of alpine spring environments. As a consequence, the information collected in this way would allow a progressively greater improvement of the management and conservation of alpine springs.

\section{Study area and methods}

The R.Po is the principal Italian watercourse with a total length of $672 \mathrm{~km}$. The study was undertaken in the upper $30 \mathrm{~km}$ of the Po valley, which is situated in western Piedmont, NW Italy and borders with the Ubaye-Durance-Rhone river basin in France. The source of the R.Po is situated along the lower slopes of Mount Viso $(3,841 \mathrm{~m}$ a.s.l., the highest peak in this sector the Alps). The valley descends with a strong slope (10\%) for about $15 \mathrm{~km}$ before it reaches the plain, characterized by intensive agriculture (cereals and fruit). The main axis of the alpine chain in this area runs from $\mathrm{N}$ to $\mathrm{S}$ and the Po runs from $\mathrm{W}$ to $\mathrm{E}$; the upper Po basin is bordered to the $\mathrm{N}$ and to the $\mathrm{S}$ by secondary mountain chains separating it from the R. Varaita basin to the $\mathrm{S}$ and from the R.Pellice basin to the $\mathrm{N}$.

The Mount Viso complex originated from magmatic rocks and deposits on the bottom of the ancient Tethys Sea which were successively metamorphosized during the orogenesis of the Alps in the Mesozoic (Eusebio et al., 2010). The present bedrock of the study area around Mount Viso can be ascribed to formations of 
schists and ophiolites of the southern Cotian Alps. On the surface, a significant proportion of the rocky substratum is the result o glacial activities. Below the Mount Viso complex, the villages of Crissolo and Oncino are located in an area characterized by calcareous and dolomitic rocks of karstic nature. Further downstream, gneiss and mica schist formations are found. Various cristalline rock formations are also present. In the area of Ostana and Crissolo, rocks containing iron mineral appear. Finally, the plains are made of Quaternary deposits of alluvial origin.

Benthic diatoms were sampled in the summer of 2010 in the 7 springs and headwaters shown in Figure 1. Sampling locations were situated in the Po fluvial natural Park in the Piedmont administrative region, Cuneo province, at altitudes ranging from 264 to 2,020 $\mathrm{m}$ a.s.1. These include the spring which is considered to be the source of the R.Po and 6 other springs situated in the lateral valleys and in the plain. Summary data for all of the sampling locations, including prevalent local lithology and land cover recorded in the field according to the classification of Regione Piemonte (2008), are given in Table 1. Springs 1-4 can be considered as relatively high altitude stations, while the remaining three springs (5-7) can be defined as relatively low altitude locations. Spring 4 was characterized by a low discharge and a thin veil of water, which allowed the sampling of diatoms but not of water. In the remaining 6 springs, temperature, $\mathrm{pH}$, dissolved oxygen and conductivity were measured in the field by means of a multiparametric probe (Hydrolab, model QUANTA GTM), while water samples were taken to the ARPA laboratory in Cuneo where analysis of silicates was undertaken according to APAT/CNR-IRSA (2003) protocols.

Standard diatom sampling protocols were applied (Kelly et al., 1998). About 400 valves were counted for each sample. Remaining valves on the slides were also examined in order to include the possible rare species (abundance $<1 / 400$ ) in order to estimate the total taxonomic richness for each sample. For diatom identification, taxonomic keys and other publications were used, including Lange-Bertalot \& Metzeltin (1996), Krammer (2000), Lange-Bertalot (2001), Krammer (2002) and Krammer (2003). Water quality indices EPI-D (Dell'Uomo, 2003), IPS (CEMA-

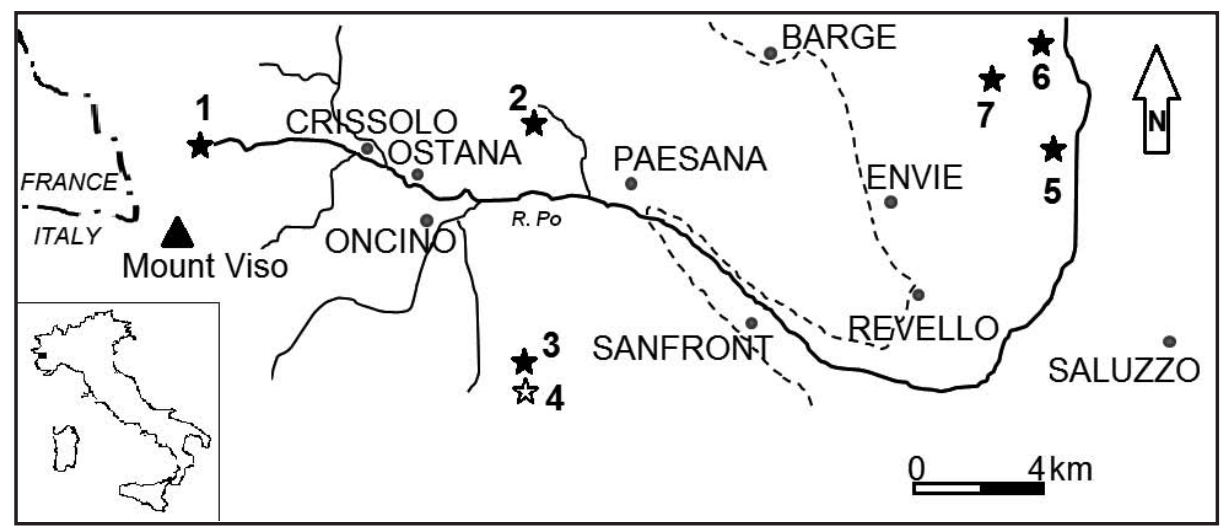

Fig. 1 - Study area showing with positions of the springs given by $\star$ (diatom sampling and water chemistry analysis) and is (only diatom sampling).

Fig. 1 - Area dello studio con localizzazione delle sorgenti indicata dal simbolo $\star$ (prelievo di diatomee e rilevamento parametri chimici) e $\mathbf{z}$ (solo prelievo di diatomee). 
GREF, 1982) and TI (Rott et al., 1999) were calculated for all spring samples. The EPI-D index was chosen because it was the first diatom index developed for Italy; IPS and TI were chosen because they have been officially adopted as metrics for routine monitoring of Italian watercourses (Italia, 2011). Multi-variate techniques were applied to the data set, using a dedicated software (McCune \& Mefford, 1999). In order to individuate underlying trends linking chemical and taxonomical data, an ordination (Canonical Correspondence Analysis, CCA) was performed on the 25 most important taxa (considered to be those present with at least 10 individuals in at least one of the counts of the 6 spring samples on which CCA was applied) and on the 5 most significant variables, selected by performing a preliminary multiple regression. The 25 selected taxa are those in bold characters in Appendix 1. The choice of CCA as the multi-variate technique was based on a preliminary Detrended Correspondence Analysis (DCA) on the taxonomic data which showed a total gradient value of 5.1 standard deviation units for axis 1, indicating a unimodal distribution of the taxonomical abundance data (ter Braak \& Prentice, 1988).

Tab. 1 - Summary data of springs sampled in the present study with indication of altitude, prevalent lithology and land cover according to Regione Piemonte (2008). Tab. 1 - Dati riassuntivi delle sorgenti campionate nel presente studio con indicazione dell'altitudine, della litologia prevalente e della land cover (Regione Piemonte, 2008).

\begin{tabular}{|c|c|l|c|l|l|}
\hline Springs & \multicolumn{2}{|c|}{ UTM coordinates } & $\begin{array}{c}\text { Altitude } \\
{[\mathrm{m} \text { a.s.1.] }}\end{array}$ & Prevalent lithology & \multicolumn{1}{|c|}{ Land Cover } \\
\hline 1 & 348960 & 4951630 & 2020 & gabbro and prasinites & Scarce vegetation \\
\hline 2 & 360120 & 4951950 & 1350 & gneiss and quartzites & Forest \\
\hline 3 & 359530 & 4944330 & 1860 & gneissic mica schists & Meadow/pasture \\
\hline 4 & 359670 & 4943700 & 1850 & gneissic mica schists & Meadow/pasture \\
\hline 5 & 376630 & 4951430 & 270 & quaternary deposits & Arable land \\
\hline 6 & 375770 & 4954430 & 264 & quaternary deposits & Arable land \\
\hline 7 & 374780 & 4952620 & 270 & quaternary deposits & Forest \\
\hline
\end{tabular}

\section{Results}

The results of water chemistry measurements and analyses are given in Table 2. Electric conductivity, as expected, tended to increase with the decrease in altitude, while silicate content ranged from 2.5 to $5.6 \mathrm{mg} \mathrm{l}^{-1}$ in the three higher altitude sites and from 21.0 to $22.2 \mathrm{mg}^{-1}$ in the lower three springs. $\mathrm{pH}$ was close to neutrality in five springs and slightly acidic (5.2) in spring 3. Dissolved oxygen was always above $89 \%$ saturation.

A total of 101 species belonging to 35 genera were identified. Gomphonema and Navicula were the genera with the highest richness (13 and 9 species or varieties, respectively), while in terms of individual abundance the dominant genera were Diatoma and Achnanthidium followed by Eunotia, Gomphonema and Fragilaria. The check-list of all the species found in this study is given in Appendix 1.

Springs 6 and 7, both situated in the lower part of the study area, showed the highest diatomic biodiversity (richness), with 52 and 38 species, respectively. Lowest species richness was found in spring 3 (12 species), one of the relatively higher 
Tab. 2 - Values of the parameters temperature, electric conductivity, $\mathrm{pH}$, dissolved oxygen, silica for springs 1, 2, 3, 5, 6 and 7. Water samples were not taken in spring 4. Tab. 2 - Valori dei parametri temperatura, conducibilità elettrica, $\mathrm{pH}$, ossigeno disciolto e silicati per le sorgenti 1, 2, 3, 5, 6 e 7 . Non sono stati presi campioni d'acqua nella sorgente 4.

\begin{tabular}{|l|r|r|r|r|r|r|}
\hline Spring & \multicolumn{1}{|c|}{$\mathbf{1}$} & \multicolumn{1}{|c|}{$\mathbf{2}$} & \multicolumn{1}{c|}{$\mathbf{3}$} & \multicolumn{1}{c|}{$\mathbf{5}$} & \multicolumn{1}{c|}{$\mathbf{6}$} & \multicolumn{1}{c|}{7} \\
\hline $\mathrm{pH}$ & 7.8 & 7.0 & 5.2 & 6.4 & 6.9 & 6.9 \\
\hline Electric conductivity $\left(\mu \mathrm{S} \mathrm{cm}^{-1}\right)$ & 85 & 18 & 21 & 316 & 316 & 205 \\
\hline Temperature $\left({ }^{\circ} \mathrm{C}\right)$ & 3.4 & 13.0 & 8.8 & 13.3 & 13.1 & 13.7 \\
\hline Dissolved oxygen $\left(\mathrm{mg} \mathrm{l}^{-1}\right)$ & 12.9 & 10.9 & 12.0 & 10.0 & 10.6 & 9.3 \\
\hline \% saturation Dissolved oxygen & 97.3 & 105.0 & 103.6 & 96.0 & 101.2 & 89.6 \\
\hline Silica $\left(\mathrm{mg} \mathrm{l}^{-1}\right)$ & 2.6 & 5.6 & 2.5 & 21.0 & 21.3 & 22.2 \\
\hline
\end{tabular}

altitude stations. Diatoma mesodon and Achnanthidium minutissimum were the overall most abundant species, accounting for 21.6 and $18.3 \%$ of the total counted individuals, respectively. $D$. mesodon is pollution-sensitive and typical of low trophic levels, while A. minutissimum requires well oxygenated waters but tolerates a wide range of trophic conditions, from oligotrophic to eutraphentic (Van Dam, 1994). Next most abundant species are Planothidium lanceolatum $(8.7 \%)$ and Eunotia exigua $(7.2 \%)$ followed at a distance by Meridion circulare (4.4\%), Psammothidium chlidanos (4.0\%), Ulnaria biceps $(3.2 \%)$ and all the others. Observing the species distribution within stations, $D$. mesodon was dominant in two high altitude springs (R.Po spring n.1 at Crissolo and R.Agliasco spring 2 near Paesana). Other dominant species were E. exigua in the high altitude R.Croesio spring 3 (the same one with lowest taxonomic richness), while in the remaining stations the relatively more abundant species were $A$. minutissimum in springs 4, 5 and 6 and $P$. lanceolatum in spring 7 at Staffarda. Other occasionally abundant species were $P$. chlidanos in spring 3, $M$. circulare and $U$. biceps in spring 5.

In Figure 2, some images of diatoms found in this study are given. Among the less common taxa, Gomphonema nathorstii, described by Foged (1964) and reported by Metzeltin (in Reichardt, 1999) for Spitsbergen Island situated in the northern arctic circle, was found in spring 4 . This finding of a rare arctic species so far South of the described area of the original finding is of great interest.

Values of diatom indices for the different samples (expressed in the standard 1-20 scale of increasing water quality) are given in Table 3. TI index ranged from 6.8 to 17.4 , with a slight difference between mean values for lowland and upstream sites (8.2 and 14.1, respectively). Small differences were also observed between average values of the other indices calculated for high and low altitude sites (19.0 and 16.5 for IPS and 16.5 and 15.7 for EPI-D, respectively), indicating -as expected- higher quality values in the higher altitude springs. However, in terms of biodiversity, the lowland springs (with an average of 38.0 taxa) were richer in taxa than those situated at higher altitudes (20.3).

The ordination undertaken with the CCA was characterized by eigenvalues of 0.84 (axis 1), 0.76 (axis 2) and 0.46 (axis 3), while $36 \%$ of the total variance of the taxonomic data was explained by the first axis, $33 \%$ by the second and $20 \%$ by the third. A Monte-Carlo permutation test (499 runs) showed that the species- 

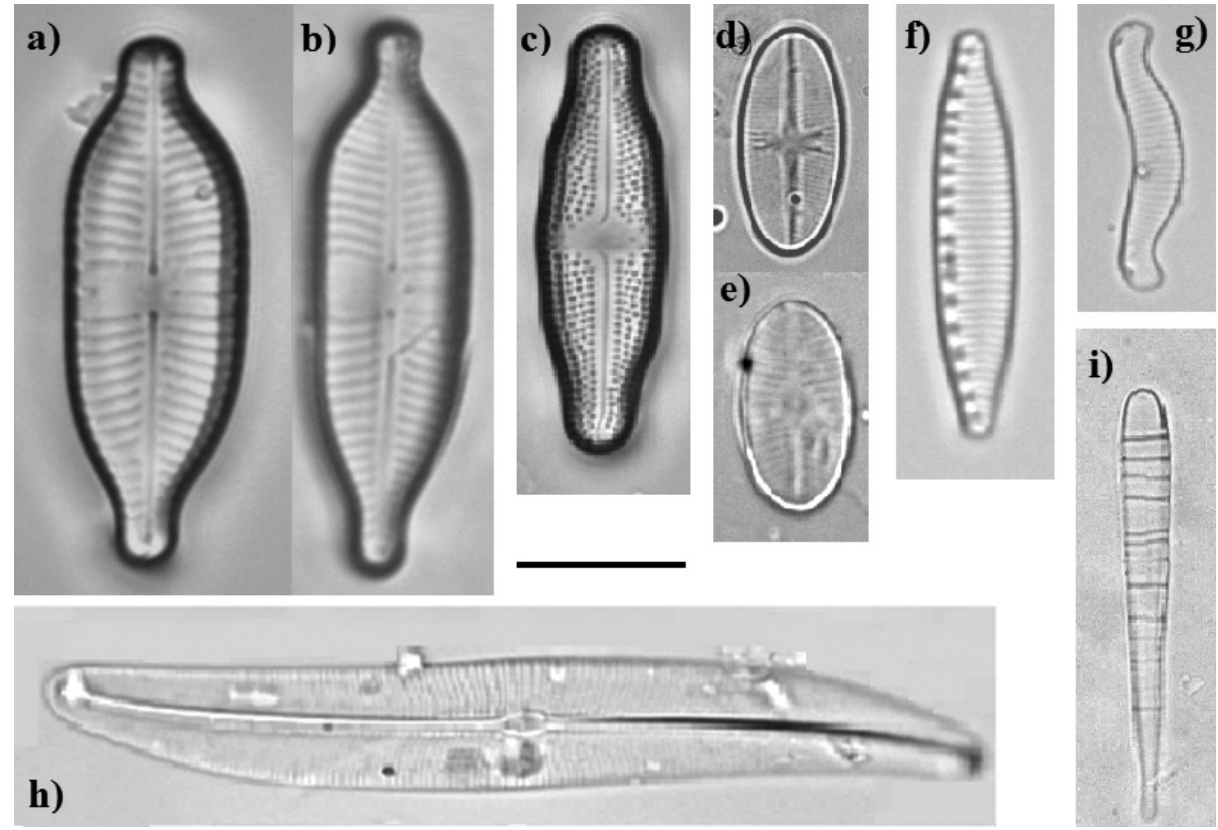

h)

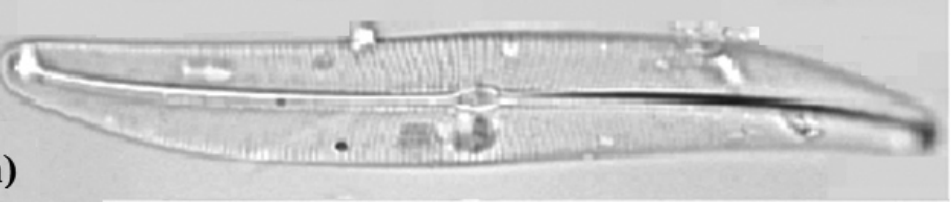

Fig. 2 - LM (1000x) photographs of some of the species found in the present study.: a) and b) Gomphonema nathorstii, a rare species described for arctic regions, found in spring 4 ; c) Luticola dismutica found in springs 1 and 2; d) and e) Planothidium chlidanos, abundant in spring 3; f) Nitzschia hantzschiana found in spring 4; g) Eunotia exigua, dominant diatom in spring 3; h) Gyrosigma obtusatum observed in spring 6; i) Meridion circulare, abundant in spring 5. For all photos the scale bar represents $10 \mu$. Fig. 2 - Microfotografie (1000x) di alcune delle specie rinvenute nel corso del presente studio: a) e b) Gomphonema nathorstii, una specie rara descritta per le regioni Artiche, campionata nella sorgente 4; c) Luticola dismutica rinvenuta nelle sorgenti 1 e 2; d) ed e) Planothidium chlidanos, abbondante nella sorgente 3; f) Nitzschia hantzschiana trovata nella sorgente 4; g) Eunotia exigua, diatomea dominante nella sorgente 3; h) Gyrosigma obtusatum osservata nella sorgente 6; i) Meridion circulare, abbondante nella sorgente 5 . Per tutte le foto la barra della scala corrisponde a $10 \mu$.

Tab. 3 - Values of taxonomic richness and of the diatom water quality indices EPI-D, IPS and TI (see text).

Tab. 3 - Valori del numero di specie e degli indici diatomici di qualità dell'acqua EPI-D, IPS e TI (vedere testo).

\begin{tabular}{|c|c|c|c|c|}
\hline Spring & N. of taxa & EPI-D & IPS & TI \\
\hline 1 & 18 & 16.8 & 18.6 & 17.4 \\
\hline 2 & 20 & 15.5 & 19.2 & 15.7 \\
\hline 3 & 12 & 17.1 & 19.5 & 8.7 \\
\hline 4 & 31 & 16.4 & 18.5 & 14.6 \\
\hline 5 & 24 & 16.3 & 17.6 & 9.7 \\
\hline 6 & 52 & 13.6 & 14.1 & 8.1 \\
\hline 7 & 38 & 17.1 & 17.9 & 6.8 \\
\hline
\end{tabular}


environment correlations were significant $(p=0.05)$. The triplot of the first two axes of the CCA with samples, the main taxa and the environmental variables is shown in Figure 3. It can be observed that $\mathrm{pH}$ was strongly and negatively correlated with axis 1, while DO was positively correlated with axis 2 and water temperature, conductivity and silica were negatively correlated with axis 2. Springs 1 and 2 were well correlated with high dissolved oxygen and $\mathrm{pH}$ values, while spring 3 was correlated to high DO but low $\mathrm{pH}$ values. The lowland springs 5, 6 and 7 were correlated to low DO and high temperature, conductivity and silica values.

\section{Discussion and Conclusions}

The investigated springs could be ascribed to 3 different categories. The first was characterized by alkaline and well oxygenated waters and was strongly associated with the presence of species such as D. mesodon and Gomphonema micropus (springs 1 and 2). The second group included well oxygenated waters associated with species like $P$. chlidanos and E. exigua (including spring 3), while the category grouping lowland springs was characterized by circumneutral $\mathrm{pH}$ associated with several species including A. minutissimum,

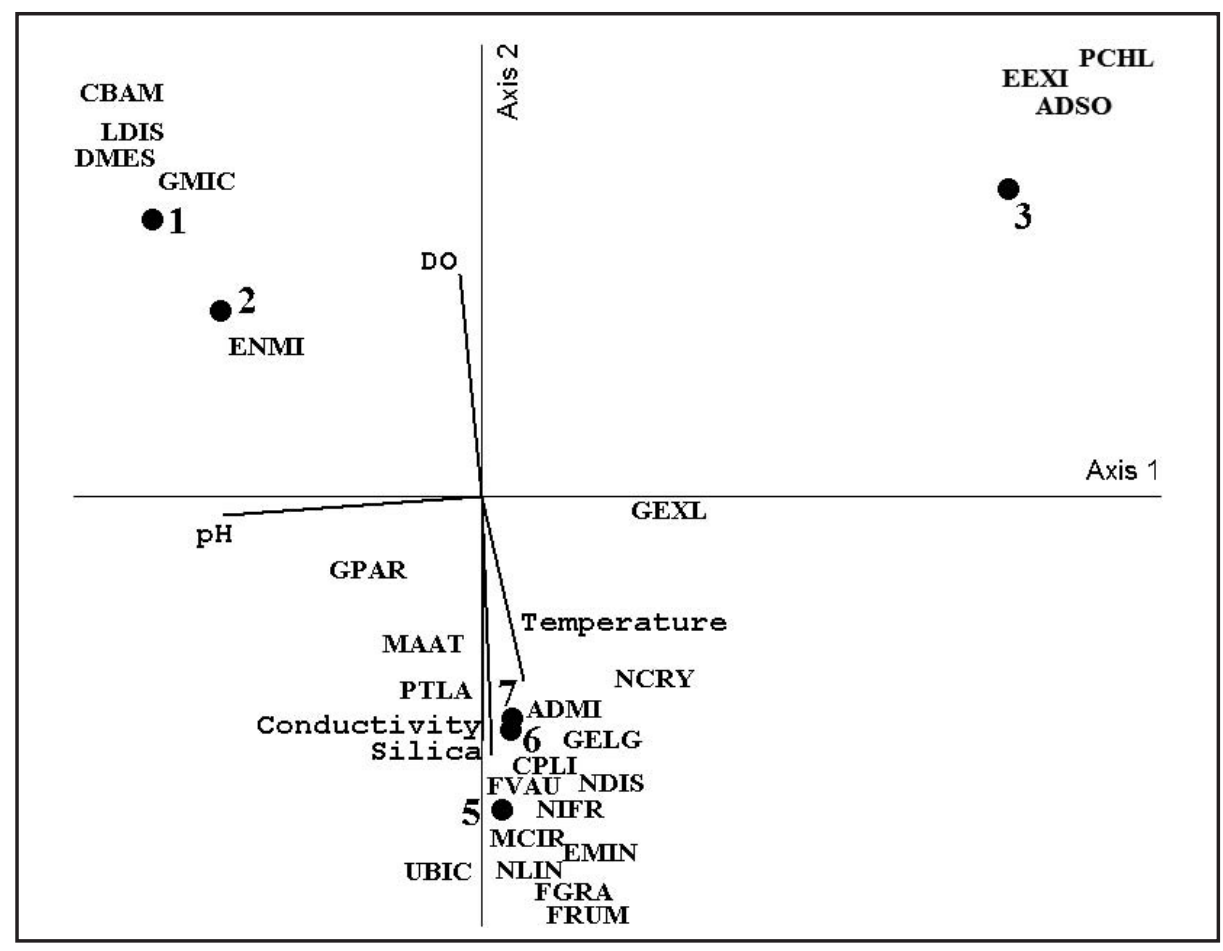

Fig. 3 - CCA triplot for the first 2 axes of the ordination, showing the 6 springs where environmental data were available, the 6 environmental variables represented by vectors and the 25 most representative species (for complete species names represented by the codes, see Appendix 1).

Fig. 3 - Diagramma della CCA riportante i primi due assi dell'ordinamento, con rappresentazione dei 6 campioni, delle 6 variabili ambientali rappresentate da vettori e delle 25 specie più rappresentative (per il nome completo delle specie indicate con codici si veda l'Appendice 1). 
P. lanceolatum and $N$. linearis. It is plausible that diatom associations identified in springs 4 and 3 are similar due to their close location and similar lithology and land cover. A future development of this first study will be to compare the results with those of other similar studies undertaken in various sectors of the western Italian Alps (Battegazzore et al., 2004; Falasco \& Bona, 2011) in order to obtain a wider picture including other taxa and environmental conditions.

From the point of view of endangered species, 90 of the 101 species found are considered in the sole Red List of diatom species existing in Europe (LangeBertalot \& Steindorf, 1996). Among these, $19(21.1 \%)$ are classified as endangered in different degrees, for $28(31.1 \%)$ the risk is not estimated and $43(47.8 \%)$ are classified as not threatened. These figures should be considered with some caution, because the German Red List of diatom taxa may not be perfectly representative for Italy. Moreover, among the 11 species found in this study but absent from the Red List are extremely rare species such as $G$. nathorstii which were not previously recorded for Italy and neither for Germany.

Springs are vulnerable habitats, of strategic importance to the biodiversity of the territories that surround them, but are generally excluded from biological water quality monitoring programs implemented in European countries according to the Water Framework Directive (DIR 2000/60/CE). Further studies are needed in order to evaluate the methods, criteria and reference conditions for the future monitoring of alpine springs.

\section{Acknowledgements}

Special thanks to Beppe Cavallera, Anna Gaggino, Enrico Gastaldi, Lorenzo Giordano and Ilario Mattone for their precious help in the sampling and to the colleagues of the laboratory of ARPA Piemonte in Cuneo, for the chemical analyses. For help and suggestions in taxonomic identification of diatoms I am indebted with Dr Elisa Falasco of the University of Torino and, in the case of G. nathorstii, with Prof. Horst Lange-Bertalot.

\section{References}

APAT/CNR-IRSA, 2003 - Metodi Analitici per le Acque. Quaderni APAT 29/2003, I e II, Roma.

Battegazzore M, Morisi A, Gallino B. \& Fenoglio S., 2004 - Environmental quality evaluation of alpine springs in NW Italy using benthic diatoms. Diatom Research, 19, 149-165.

Cantonati M., Bertuzzi E. \& Spitale D. (eds.), 2007 - The spring habitat: biota and sampling methods. Museo tridentino di scienze naturali, Trento.

CEMAGREFF, 1982 - Etude des méthodes biologiques d'appréciation quantitative de la qualité des eaux. Agence financiere de Bassin Rhone-Méditerranée-Corse, Pierre Bénite, Lyon.

Dell'Uomo A. 2003 - L'Indice Diatomico di Eutrofizzazione Polluzione (EPI-D) nel Monitoraggio delle Acque Correnti. Linee guida. APAT, Roma.

Ettl H. \& Gärtner G., 1995 - Syllabus der Boden-, Luft- und Flechtenalgen. Gustav Fischer Verlag, Stuttgart.

Eusebio A., Lovera U., Milanese N., Silvestro C., Veerman L. \& Vigna B., 2010 Atlante delle aree carsiche Piemontesi. Regione Piemonte, Torino. 
Falasco E. \& Bona F., 2011 - Diatom community biodiversity in al Alpine protected area: a study in the Maritime Alps natural Park. Journal of Limnology, 70 (2): 157-167.

Foged N., 1964 - Freshwater diatoms from Spitsbergen. Universitetsforlaget, Tromsö-Oslo, 204 pp.

Hàjkovà P., Shaw B., Hajek M., Hinterlang D. \& Plàšek V., 2007 - The role of base saturation and altitude in habitat differentiation within Philonotis in springs and mires of three different European regions. Bryologist, 110:776-787.

Italia, Ministero dellAmbiente, 2011 - Decreto 8 novembre 2010 n.260. Regolamento recante i criteri tecnici per la classificazione dei corpi idrici superficiali, per la modifica delle norme tecniche del decreto legislativo 3 aprile 2006 n.152, recante norme in materia ambientale, predisposto ai sensi dell'articolo 75, comma 3, del medesimo decreto legislativo. Gazzetta Ufficiale della Repubblica Italiana, 7 febbraio 2011, Serie Generale, 30: 1-190.

Kelly M.G., Cazaubon A., Coring E., Dell'Uomo A., Ector L., Goldsmith B., Guasch H., Hurlimann J., Jarlman A., Kawecka B., Kwandrans J., Laugaste R., Lindstrom E.A., Leitao M., Marvan P., Padisàk J., Pipp E., Prygiel J., Sabater S., van Dam H. and Vizinet J., 1998 - Recommendations for the routine sampling of diatoms for water quality assessments in Europe. Journal of Applied Phyco$\log y, 10: 215-224$.

Krammer K., 2000 - The Genus Pinnularia. Diatoms of Europe. Diatoms of the European Inland Waters and Comparable Habitats. Lange-Bertalot H. (ed.). Gantner Verlag, Rugell, 1.

Krammer, K., 2002 - Cymbella. Diatoms of Europe. Diatoms of the European Inland Waters and Comparable Habitats. Lange-Bertalot H. (ed.). Gantner Verlag, Rugell, 3.

Krammer, K., 2003 - Cymbopleura, Delicata, Navicymbula, Gomphocymbellopsis, Afrocymbella. Diatoms of Europe. Diatoms of the European Inland Waters and Comparable Habitats. Lange-Bertalot H. (ed.). Gantner Verlag, Rugell, 4.

Lange-Bertalot H. \& Steindorf A., 1996 - Rote Liste der limnische Kieselalgen (Bacillariophyceae) Deutschlands. Schriftenreihe fur Vegetationskunde, 28: 633-677.

Lange-Bertalot H. \& Metzeltin D., 1996 - Indicators of oligotrophy. Iconographia diatomologica, Koeltz Scientific Books, 2.

Lange Bertalot, H., 2001 - Navicula sensu stricto, 10 Genera Separated from Navicula sensu stricto, Frustulia. Diatoms of Europe. Diatoms of the European Inland Waters and Comparable Habitats. Lange-Bertalot H. (ed.). Gantner Verlag, Rugell, 2.

Longhurst A. R., Sathyendranath S., Platt T. \& Caverhill C., 1995 - An estimate of global primary production in the ocean from satellite radiometer data. Journal of Plankton Research, 17: 1245-1271.

Mann D. G. \& Droop S. J. M., 1996-Biodiversity, biogeography, and conservation of diatoms. In: Proceedings of the workshop on Biogeography of freshwater algae, developments in hydrobiology. Cristiansen J. (ed.). Kluwer, Dordrecht, 19-32.

McCune B. \& Mefford M. J., 1999 - Multivariate analysis of ecological data, version 4. MJM Software Design, Gleneden Beach, Oregon, USA.

Orendt C., 2000 - Chironomids of small Alpine water bodies (springs, spring brooks, pools, small lakes) of the Northern calcareous Alps (Insecta, Diptera, Chironomidae). Spixiana, 23 (2): 121-128. 
Regione Piemonte, 2008 - Land Cover Piemonte LCP v02-2008, http://www. regione.piemonte.it/repimgw2/main.php - last consulted on 01/08/2011

Reichardt, E., 1999 - Zur revision der Gattung Gomphonema. Iconographia Diatomologica. Gantner Verlag, Rugell, 8.

Rott E., Binder N., Van Dam H., Ortler K., Pall K., Pfister P., Pipp E., 1999 - Indikationslisten für Aufwuchsalgen. Teil 2. Trophieindikation und autökologische Anmerkungen. Bundesministerium für Land- und Forstwirtschaft, Wien.

Ter Braak C. J. F. \& Prentice I. C., 1988 - A theory of gradient analysis. Adv. Ecol. Res. 18: 271-313.

Tréguer P., Nelson D. M., van Bennekom A. J., DeMaster D. J., Leynaert A. \& Quéginer B., 1995 - The silica balance in the world ocean: a reestimate. Science, 268: 375-379.

Van Dam H., Mertens A. \& Sinkeldam J., 1994 - A coded check list and ecological indicator values of freshwater diatoms the Netherlands. Netherlands Journal of Aquatic Ecology, 28 (1), 117-133.

Werner D. (ed.), 1977 - The Biology of Diatoms. University of California Press, Berkeley.

Appendix 1 - Relative abundances of all identified taxa in the 7 sampled springs, with indication of the corresponding codes and their status according to Red List criteria of threatened species (R.L.) The classes of abundance are given as follows: + (up to 9 individuals), ++ (from 10 to 74 individuals and +++ (75 individuals or more). The meanings of the symbols of Red List status (Lange-Bertalot $\&$ Steindorf, 1996) are: $0=$ almost extinct, $1=$ threatened by extinction, $2=$ strongly threatened, $3=$ endangered, $\mathrm{G}=$ existing risk, $\mathrm{R}=$ very rare, $\mathrm{V}=$ in regression, $*=$ risk not estimated, $\mathrm{D}=$ insufficient data, ?=not endangered. The 25 species used in the multivariate analysis (CCA) are those in bold character.

Appendice 1 - Abbondanze relative di tutti i taxa identificati nelle 7 sorgenti campionate, con indicazione del corrispondente codice e loro status rispetto alla Lista Rossa (R.L.) delle diatomee minacciate. Le classi di abbondanza sono indicate come segue: + (fino a 9 individui), ++ (da 10 a 74 individui e +++ (75 individui e oltre). I simboli dello status secondo i criteri della Lista Rossa (Lange-Bertalot \& Steindorf, 1996) sono: $0=$ quasi estinta, $1=$ minacciata di estinzione, $2=$ fortemente minacciata, $3=$ minacciata, $\mathrm{G}=$ rischio esistente, $\mathrm{R}=$ molto rara, $\mathrm{V}=$ in regressione, * $=$ rischio non stimato, $\mathrm{D}=$ dati insufficienti, $?=$ non in pericolo. Le 25 specie utilizzate nell'analisi multivariata (CCA) sono quelle in neretto.

\begin{tabular}{|l|l|c|c|c|c|c|c|c|c|}
\hline & & & \multicolumn{7}{|c|}{ SPRING } \\
\hline CODE & TAXON & R.L. & $\mathbf{1}$ & $\mathbf{2}$ & $\mathbf{3}$ & $\mathbf{4}$ & $\mathbf{5}$ & $\mathbf{6}$ & $\mathbf{7}$ \\
\hline ACLI & Achnanthidium lineare W. Smith & 3 & + & + & & + & + & + & + \\
\hline ADMI & $\begin{array}{l}\text { Achnanthidium minutissimum } \\
\text { (Kützing) Czarnecki }\end{array}$ & $?$ & + & + & ++ & +++ & +++ & +++ & +++ \\
\hline ADPY & $\begin{array}{l}\text { Achnanthidium pyrenaicum } \\
\text { (Hustedt) Kobayasi }\end{array}$ & $?$ & + & + & + & + & & & \\
\hline ADSO & $\begin{array}{l}\text { Achnanthidium subatomoides } \\
\text { (Hustedt) Monnier, Lange-Bertalot } \\
\text { \& Ector }\end{array}$ & V & & & & + & ++ & & \\
\hline
\end{tabular}




\begin{tabular}{|c|c|c|c|c|c|c|c|c|c|}
\hline & & & \multicolumn{7}{|c|}{ SPRING } \\
\hline CODE & TAXON & R.L. & 1 & 2 & 3 & 4 & 5 & 6 & 7 \\
\hline AMMO & Amphora montana Krasske & $*$ & & & & & & + & \\
\hline APED & $\begin{array}{l}\text { Amphora pediculus (Kützing) } \\
\text { Grunow }\end{array}$ & $?$ & & & & & & & + \\
\hline APEL & Amphipleura pellucida Kützing & $*$ & & & & & & & + \\
\hline CAFF & Cymbella affinis Kützing var. affinis & & & & & + & & & \\
\hline CBAM & $\begin{array}{l}\text { Cymbopleura amphicephala } \\
\text { Krammer }\end{array}$ & V & ++ & & & & & & \\
\hline CCUS & Cymbella cuspidata Kützing & V & & & & & & & + \\
\hline CDUB & $\begin{array}{l}\text { Cyclostephanos dubius (Fricke) } \\
\text { Round }\end{array}$ & $?$ & + & & & & & & \\
\hline CEUG & Cocconeis euglypta Ehrenberg & $?$ & & & + & & & & \\
\hline CMEN & Cyclotella meneghiniana Kützing & $?$ & & & & & & + & \\
\hline CPLI & $\begin{array}{l}\text { Cocconeis placentula Ehrenberg } \\
\text { var. lineata (Ehr.) Van Heurck }\end{array}$ & $?$ & & & & + & & & ++ \\
\hline CSAQ & $\begin{array}{l}\text { Cymbopleura subaequalis (Grunow) } \\
\text { Krammer var. subaequalis }\end{array}$ & G & & & & + & & & \\
\hline CSIL & Caloneis silicula (Ehr.) Cleve & * & & & & & + & & \\
\hline DFON & Diploneis fontanella Lange-Bertalot & & & & & + & & & \\
\hline DHIE & $\begin{array}{l}\text { Diatoma hyemalis (Roth) Heiberg } \\
\text { var. hyemalis }\end{array}$ & $*$ & + & & & & & & \\
\hline DMES & $\begin{array}{l}\text { Diatoma mesodon (Ehrenberg) } \\
\text { Kützing }\end{array}$ & $*$ & +++ & +++ & & +++ & & + & \\
\hline DPER & $\begin{array}{l}\text { Diadesmis perpusilla (Grunow) } \\
\text { D.G. Mann in Round et al. }\end{array}$ & $?$ & & + & & + & & & \\
\hline DTEN & Denticula tenuis Kützing & $*$ & & + & & & & & \\
\hline DVUL & Diatoma vulgaris Bory & $\mathrm{D}$ & + & & & + & & & \\
\hline EBIL & $\begin{array}{l}\text { Eunotia bilunaris (Ehr.) Mills var. } \\
\text { bilunaris }\end{array}$ & $?$ & & & & & & & + \\
\hline EEXI & $\begin{array}{l}\text { Eunotia exigua (Brebisson ex } \\
\text { Kützing) Rabenhorst }\end{array}$ & $?$ & & + & +++ & & & & + \\
\hline EMIN & $\begin{array}{l}\text { Eunotia minor (Kützing) Grunow in } \\
\text { Van Heurck }\end{array}$ & $*$ & & + & & & ++ & ++ & \\
\hline ENMI & $\begin{array}{l}\text { Encyonema minutum (Hilse in } \\
\text { Rabh.) D.G. Mann }\end{array}$ & $*$ & & ++ & + & ++ & & & + \\
\hline ESLE & $\begin{array}{l}\text { Encyonema silesiacum (Bleisch in } \\
\text { Rabh.) D.G. Mann }\end{array}$ & $*$ & & & & + & + & + & + \\
\hline EULA & $\begin{array}{l}\text { Eucocconeis laevis (Oestrup) Lange- } \\
\text { Bertalot }\end{array}$ & $*$ & & & & + & & & \\
\hline FARC & $\begin{array}{l}\text { Fragilaria arcus (Ehrenberg) Cleve } \\
\text { var. arcus }\end{array}$ & $?$ & + & & & + & & & \\
\hline FCSE & $\begin{array}{l}\text { Fragilaria capucina Desm. var. } \\
\text { septentrionalis (Oestrup) } \\
\text { Lange-Bertalot }\end{array}$ & & & & & & & + & \\
\hline
\end{tabular}




\begin{tabular}{|c|c|c|c|c|c|c|c|c|c|}
\hline \multirow[b]{2}{*}{ CODE } & \multirow[b]{2}{*}{ TAXON } & \multirow[b]{2}{*}{ R.L. } & \multicolumn{7}{|c|}{ SPRING } \\
\hline & & & 1 & 2 & 3 & 4 & 5 & 6 & 7 \\
\hline FGRA & Fragilaria gracilis Østrup & $*$ & & & & + & ++ & + & \\
\hline FNOP & $\begin{array}{l}\text { Fragilaria neoproducta } \\
\text { Lange-Bertalot }\end{array}$ & + & & & & & & + & \\
\hline FPEM & $\begin{array}{l}\text { Fragilaria perminuta (Grunow) } \\
\text { Lange-Bertalot }\end{array}$ & $*$ & & + & & & & & \\
\hline FRUM & $\begin{array}{l}\text { Fragilaria rumpens (Kütz.) } \\
\text { G.W.F. Carlson }\end{array}$ & $*$ & & & & & + & ++ & \\
\hline FTEN & $\begin{array}{l}\text { Fragilaria tenera (W. Smith) Lange- } \\
\text { Bertalot }\end{array}$ & $\mathrm{V}$ & & & & & & + & + \\
\hline FVAU & $\begin{array}{l}\text { Fragilaria vaucheriae (Kützing) } \\
\text { Petersen }\end{array}$ & $?$ & & ++ & & + & + & & + \\
\hline FVUL & $\begin{array}{l}\text { Frustulia vulgaris (Thwaites) } \\
\text { De Toni }\end{array}$ & $?$ & & & & & & + & + \\
\hline GACU & $\begin{array}{l}\text { Gomphonema acuminatum } \\
\text { Ehrenberg }\end{array}$ & $?$ & & & & & & + & + \\
\hline GANG & $\begin{array}{l}\text { Gomphonema angustatum (Kützing) } \\
\text { Rabenhorst }\end{array}$ & $*$ & & & + & & + & & + \\
\hline GANT & Gomphonema angustum Agardh & V & + & + & & & & & \\
\hline GAUG & Gomphonema augur Ehrenberg & $*$ & & & & & & + & \\
\hline GCLA & Gomphonema clavatum Ehrenberg & $*$ & & & & & & + & + \\
\hline GELG & $\begin{array}{l}\text { Gomphonema elegans (Reichardt \& } \\
\text { Lange-Bertalot) Monnier \& Ector }\end{array}$ & $*$ & & & & & & ++ & \\
\hline GEXL & $\begin{array}{l}\text { Gomphonema exilissimum (Grun.) } \\
\text { Lange-Bertalot \& Reichardt }\end{array}$ & $\mathrm{V}$ & & & & + & ++ & ++ & \\
\hline GMAE & $\begin{array}{l}\text { Gomphonema micropus var. aequale } \\
\text { (Gregory) Reichardt }\end{array}$ & & & + & & & & & \\
\hline GMIC & $\begin{array}{l}\text { Gomphonema micropus Kützing } \\
\text { var. micropus }\end{array}$ & $*$ & ++ & & + & ++ & & + & + \\
\hline GNAT & Gomphonema nathorstii Foged & & & & & + & & & \\
\hline GOLI & $\begin{array}{l}\text { Gomphonema olivaceum } \\
\text { (Hornemann) Brébisson var. } \\
\text { olivaceum }\end{array}$ & $?$ & & & & + & & & + \\
\hline GPAR & $\begin{array}{l}\text { Gomphonema parvulum (Kützing) } \\
\text { Kützing var. parvulum f. parvulum }\end{array}$ & $?$ & + & & & ++ & & & + \\
\hline GSCL & Gomphonema subclavatum Grunow & $*$ & & & & + & + & & \\
\hline GTER & Gomphonema tergestinum Fricke & G & + & & & & & & \\
\hline GYOB & $\begin{array}{l}\text { Gyrosigma obtusatum (Sullivan \& } \\
\text { Wormley) Boyer }\end{array}$ & & & & & & & + & \\
\hline HAMP & $\begin{array}{l}\text { Hantzschia amphioxys (Ehr.) } \\
\text { Grunow in Cleve et Grunow } 1880\end{array}$ & $?$ & & & & & + & + & + \\
\hline KOBG & $\begin{array}{l}\text { Karayevia oblongella (Oestrup) } \\
\text { M. Aboal }\end{array}$ & $\mathrm{V}$ & & + & & & & & + \\
\hline
\end{tabular}




\begin{tabular}{|c|c|c|c|c|c|c|c|c|c|}
\hline & & & \multicolumn{7}{|c|}{ SPRING } \\
\hline CODE & TAXON & R.L. & 1 & 2 & 3 & 4 & 5 & 6 & 7 \\
\hline LDIS & $\begin{array}{l}\text { Luticola dismutica (Hustedt) } \\
\text { D.G. Mann }\end{array}$ & $\mathrm{R}$ & ++ & + & & & & & \\
\hline LMUT & Luticola mutica (Kützing) D.G. Mann & $?$ & & & & & & + & + \\
\hline MAAT & $\begin{array}{l}\text { Mayamaea atomus (Kutzing) } \\
\text { Lange-Bertalot }\end{array}$ & $?$ & & ++ & & & & ++ & \\
\hline MCIR & $\begin{array}{l}\text { Meridion circulare (Greville) } \\
\text { C.A. Agardh var. circulare }\end{array}$ & $?$ & + & & & + & +++ & + & + \\
\hline MVAR & Melosira varians Agardh & $?$ & & & & & & + & \\
\hline NAMP & $\begin{array}{l}\text { Nitzschia amphibia Grunow f. } \\
\text { amphibia }\end{array}$ & $*$ & & & & & & & + \\
\hline NANT & Navicula antonii Lange-Bertalot & $?$ & + & + & & & & & \\
\hline NCPL & $\begin{array}{l}\text { Nitzschia capitellata Hustedt in } \\
\text { A. Schmidt } \text { et al. }\end{array}$ & $?$ & & & + & & & & \\
\hline NCRY & Navicula cryptocephala Kützing & $?$ & & & + & & + & ++ & \\
\hline NCTE & $\begin{array}{l}\text { Navicula cryptotenella } \\
\text { Lange-Bertalot }\end{array}$ & $?$ & & & & & & + & + \\
\hline NDIS & $\begin{array}{l}\text { Nitzschia dissipata (Kützing) } \\
\text { Grunow var. dissipata }\end{array}$ & $?$ & & & & + & & ++ & + \\
\hline NFON & $\begin{array}{l}\text { Nitzschia fonticola Grunow in Cleve } \\
\text { et Möller }\end{array}$ & $?$ & & & & & & + & \\
\hline NGRE & Navicula gregaria Donkin & $?$ & & & & & & & + \\
\hline NHAN & Nitzschia hantzschiana Rabenhorst & $*$ & & & & + & & & \\
\hline NIFR & $\begin{array}{l}\text { Nitzschia frustulum (Kützing) } \\
\text { Grunow var. frustulum }\end{array}$ & $?$ & & & & & + & ++ & \\
\hline NIPF & Nitzschia paleaeformis Hustedt & $\mathrm{R}$ & + & & & & & & \\
\hline NIPM & $\begin{array}{l}\text { Nitzschia perminuta(Grunow) } \\
\text { M. Peragallo }\end{array}$ & * & & & & & & + & \\
\hline NLAN & $\begin{array}{l}\text { Navicula lanceolata (Agardh) } \\
\text { Ehrenberg }\end{array}$ & $?$ & & & & & & + & + \\
\hline NLIN & $\begin{array}{l}\text { Nitzschia linearis (Agardh) } \\
\text { W.M. Smith var. linearis }\end{array}$ & $?$ & & & & & ++ & + & + \\
\hline NPAL & Nitzschia palea (Kützing) W. Smith & $?$ & & & & & & + & \\
\hline NPNI & Navicula pseudonivalis Bock & $\mathrm{R}$ & & & & & & + & \\
\hline NPSL & $\begin{array}{l}\text { Navicula pseudolanceolata } \\
\text { Lange-Bertalot }\end{array}$ & 3 & & & & & & + & \\
\hline NRAD & Navicula radiosa Kützing & $?$ & & & & + & + & & \\
\hline NREC & $\begin{array}{l}\text { Nitzschia recta Hantzsch in } \\
\text { Rabenhorst }\end{array}$ & $?$ & & & & & & + & \\
\hline NRHY & Navicula rhynchocephala Kützing & $?$ & & & & & & + & \\
\hline NTPT & $\begin{array}{l}\text { Navicula tripunctata (O.F. Müller) } \\
\text { Bory }\end{array}$ & $?$ & & & & & & & + \\
\hline
\end{tabular}




\begin{tabular}{|c|c|c|c|c|c|c|c|c|c|}
\hline & & & \multicolumn{7}{|c|}{ SPRING } \\
\hline CODE & TAXON & R.L. & 1 & 2 & 3 & 4 & 5 & 6 & 7 \\
\hline NYCO & $\begin{array}{l}\text { Nitzschia costei Tudesque, Rimet } \\
\text { \& Ector }\end{array}$ & & & & & & & & + \\
\hline PCHL & $\begin{array}{l}\text { Psammothidium chlidanos (Hohn \& } \\
\text { Hellerman) Lange-Bertalot }\end{array}$ & 3 & & & +++ & & & & \\
\hline PINT & Pinnularia interrupta W.M. Smith & & & & & & & + & \\
\hline PLFR & $\begin{array}{l}\text { Planothidium frequentissimum } \\
\text { (Lange-Bertalot) Lange-Bertalot }\end{array}$ & $?$ & & & & & & ++ & \\
\hline PLUN & Pinnularia lundii Hustedt var. lundii & $*$ & & & & & & + & \\
\hline PMIC & $\begin{array}{l}\text { Pinnularia microstauron (Ehr.) } \\
\text { Cleve var. microstauron }\end{array}$ & $\mathrm{V}$ & & & & & & + & \\
\hline PSCA & $\begin{array}{l}\text { Pinnularia subcapitata Gregory var. } \\
\text { subcapitata }\end{array}$ & $*$ & & & & + & & & + \\
\hline PTLA & $\begin{array}{l}\text { Planothidium lanceolatum } \\
\text { (Brebisson ex Kützing) } \\
\text { Lange-Bertalot }\end{array}$ & $?$ & + & ++ & ++ & + & ++ & & +++ \\
\hline RSIN & $\begin{array}{l}\text { Reimeria sinuata (Gregory) } \\
\text { Kociolek \& Stoermer }\end{array}$ & $?$ & & + & & + & & + & + \\
\hline RUNI & $\begin{array}{l}\text { Reimeria uniseriata Sala Guerrero } \\
\text { \& Ferrario }\end{array}$ & & & & + & & & & \\
\hline SANG & Surirella angusta Kützing & $*$ & & & & & + & + & \\
\hline SAPH & Surirella amphioxys W. Smith & * & & & & & & + & \\
\hline SBRE & $\begin{array}{l}\text { Surirella brebissonii Krammer \& } \\
\text { Lange-Bertalot var. brebissonii }\end{array}$ & $?$ & & & & & & + & \\
\hline SEMN & Sellaphora minima (Grunow) Mann & $?$ & & + & & & + & + & + \\
\hline SPUP & $\begin{array}{l}\text { Sellaphora pupula (Kützing) } \\
\text { Mereschkowksy }\end{array}$ & & & & & & + & + & \\
\hline SSEM & $\begin{array}{l}\text { Sellaphora seminulum (Grunow) } \\
\text { D.G. Mann }\end{array}$ & $?$ & & & & & & + & \\
\hline STAN & Stauroneis anceps Ehrenberg & $\mathrm{V}$ & & & & & & + & \\
\hline STKR & Stauroneis kriegeri Patrick & & & & & & & + & \\
\hline SUMI & Surirella minuta Brebisson & $?$ & & & & & & & + \\
\hline UBIC & Ulnaria biceps (Kützing) Compère & G & & & & & +++ & ++ & + \\
\hline UULN & Ulnaria ulna (Nitzsch.) Compère & $*$ & & & & + & + & & + \\
\hline & TOTAL N. TAXA & & 18 & 20 & 12 & 31 & 24 & 52 & 38 \\
\hline
\end{tabular}

Ricevuto: 13 dicembre 2011

Approvato: 23 febbraio 2012 